\title{
BERNARD BEVAN (1903-1995), HISTORIADOR DE LA ARQUITECTURA ESPAÑOLA
}

Bernard Bevan, autor de la célebre Historia de la arquitectura española (Londres 1938; traducida al español por el conocido arquitecto e historiador de la arquitectura Fernando Chueca Goitia, Madrid, 1950, 2. ${ }^{\text {a }}$ ed. 1970), murió el año pasado en Rye, Inglaterra, a la edad de 92. Tanto por parte de padre como de madre, era descendiente de grandes banqueros y comerciantes (Bevans, Moriers y Bosanquets, de ascendencia hugonote estos dos últimos). Su bisabuelo, William Morier (1790-1864), fue oficial en el escuadrón de la armada inglesa que ayudó a los patriotas españoles en la defensa de Cádiz contra los invasores franceses en 1810-12. Los Bevans fueron buenos lingüistas; Ashley Bevan (1859-1933), tío de Bernard, tuvo dotes excepcionales en este aspecto, llegando a ser catedrático de árabe en la Universidad de Cambridge en 1893; se dio a conocer no sólo por sus estudios árabes, sino también persas, sirios y hebreos.

Bernard se educó principalmente en Harrow (1917-1921), un internado que ha tenido entre sus estudiantes a muchos ingleses famosos, entre otros Lord Byron y Winston Churchill. En Harrow, recordaría él más tarde, aprendió latín y griego, pero sólo consiguió detestar a aquellos autores clásicos cuyas obras servían de libros de texto para las clases. Aquellas negativas experiencias escolares no le impedirían llegar más tarde a hablar con fluidez diversas lenguas modernas, entre ellas español, italiano, francés y alemán.

Su interés por la historia del arte, que en un principio se centró en la arquitectura gótica, despertó, recordaba Bevan, cuando a los ocho años su institutriz le enseñó postales de Tintern Abbey y de la Catedral de Lincoln. A los quince poseía ya una colección considerable de libros sobre las catedrales e iglesias góticas de Europa occidental.

Al salir de Harrow continuó su educación por cuenta propia haciendo grandes viajes por Europa. En Florencia, en 1921, empezó a interesarse por la pintura y la escultura, aunque su tema favorito siguió siendo la arquitectura medieval. En 1922-24 estuvo en Lyon y en Milán. En Lyon estudió arquitectura románica bajo la especial tutela de Henri Focillon, con quien realizó un recorrido arquitectónico de Francia. Focillon le instó a continuar sus estudios en España, y así, en 1924, acompañado por su madre, cruzó los Pirineos. Ninguno de ellos sabía español todavía, pero se abrieron camino fácilmente presentándose a los párrocos, a quienes Mrs. Bevan, señora de esmerada educación, se dirigía en fluido latín, para gran sorpresa de ellos. Esta fue la primera de varias visitas a España durante las cuales Bevan viajó por todo el país y conoció, entre otros, a Manuel Cossío, al Marqués de Lozoya, a Manuel Gómez Moreno y a J. Puig i Cadafalch; también a los estudiosos americanos Mildred Stapley, Arthur Byne y, más tarde, G. G. King y Chandler Post. En 1928 empezó a escribir su historia de la arquitectura española, y en 1930 la tenía prácticamente terminada, aunque tuvo que esperar otros ocho años para verla publicada.

Entre 1925 y 1930, Bevan abordó también otros temas españoles, escribiendo artículos y reseñas para The Burlington Magazine y Apollo, y aportando las introducciones sobre escultura y arquitectura españolas para la Blue guide de Muirhead (1930). También tradujo al inglés dos clásicos de la historia del arte español, el estudio de Domínguez Bordona sobre los manuscritos iluminados y la monografía de Gómez Moreno sobre la escultura renacentista española.

Para completar sus estudios sobre la arquitectura española, Bevan viajó a México en 1930, recorrió el país de parte a parte y siguió un curso en la Universidad de México en 1931-32. El conocimiento así adquirido sobre los edificios coloniales hispanos le permitió añadir algunas valiosas páginas a su Historia. Pronto advirtió que la arquitectura colonial, aunque proyectada por españoles, había sido en realidad construida y decorada por artesanos indios; y ello le llevó a in- 
tentar comprender la mentalidad de los pueblos indios mexicanos, algunos de los cuales habían conservado gran parte de sus costumbres y modos de vida precolombinos, poco afectados por sus gobernantes europeos o criollos. Pasó varios años en el estado de Oaxaca estudiando los usos y costumbres de los indios chinantecas, mezatecas, zapotecas, mixe y mixtecas. Allí descubrió que un calendario precolombino de trece meses seguía vigente para fines agrícolas, y que los hechiceros mezatecas, concretamente en Huautle, ingerían cierta especie de hongos alucinógenos para fines advinatorios. El descubrimiento de este narcótico llevaría posteriormente al desarrollo de la droga LSD, una imprevista consecuencia que Bevan no dejó nunca de lamentar.

Bevan no limitó sus investigaciones antropológicas a Oaxaca, sino que viajó a otras partes de México y Centroamérica, casi siempre a pie; y acompañó a Jacques Soustelle en una visita al Otomi. En una expedición en 1938, recogió orquídeas que envió al Museo Botánico de Harvard. Una de estas orquídeas resultó ser de una especie hasta entonces desconocida, que el museo publicó en 1939, denominándola, en honor de su descubridor, Epidendrum Bevanii.

Tras el estallido de la II Guerra Mundial, Bevan entró en el Foreign Service y fue empleado como Secretario de Prensa en México y más tarde en Italia. Permaneció en el Foreign Service después de la guerra y ocupó diversos puestos, primero en el consulado en Barcelona (1945-48) y luego en la embajada en Lisboa, a lo que siguió la embajada en Bruselas. Más tarde fue nombrado cónsul en Madeira y concluyó su carrera en el Foreign Office en Londres como consejero en el Council of European Affairs. Se retiró, a los 60 años de edad, en 1963.

La jubilación le dejó tiempo para acometer una revisión a fondo de su Historia de la arquitectura española. Hacía falta revisar la nomenclatura y la definición de los estilos; y especialmente hacer las adecuadas referencias a la "arquitectura del manierismo", que había sido analizada y explicada por vez primera a los lectores de habla inglesa por Rudolf Wittkower en un famoso artículo en The Art Bulletin publicado en la temprana fecha de 1934. También había que reconocer la influencia ejercida en las trazas y decoraciones de los edificios españoles e hipanoamericanos por los tratados de arquitectura, en especial por las xilografías que ilustraban la Architettura de Sebastiano Serlio y el libro de modelos arquitectónicos de Wendel Dietterlin.

Bevan necesitaba obtener información y consejo de otros especialistas, y una oportunidad especialmente buena se le presentó en 1981 cuando asistió a un congreso sobre tratados de arquitectura organizado por el Centro de Estudios Superiores del Renacimiento en Tours. Allí entró en contacto con Fernando Marías y Alfonso Rodríguez de Ceballos, quienes estuvieron encantados de conocerle y de responder a sus numerosas preguntas. La revisión quedó terminada antes de su muerte, y la nueva edición será póximamente publicada con la ayuda de su hija, Ian Keir. Es esperada con impaciencia, pero la edición original no perderá su valor, especialmente para los historiógrafos.

Bernard Bevan hizo muchos amigos a lo largo de su vida y fue un corresponsal diligente. Sus cartas podían ser largas, o incluso muy largas, pero los destinatarios siempre estaban deseosos de leerlas. Gracias a sus extensos viajes, a su naturaleza observadora e inquisitiva, su excelente memoria y amplias lecturas tenía muchas cosas interesantes que decir sobre numerosas materias, y poseía el don de expresarse con originalidad y con la gracia añadida del humor. Fue hombre de gustos y aversiones fuertes. En arquitectura sus preferencias se inclinaban decididamente por los estilos medievales y por la decoración plateresca y mudéjar. El hospital Tavera, extramuros de Toledo, era uno de sus grandes favoritos. De épocas posteriores, lo que más le atraía era la arquitectura del siglo XVIII y las decoraciones mexicanas. Le interesaron mucho las artesanías y artes aplicadas relacionadas con la arquitectura, como la carpintería, la ebanistería, la metalistería, y sobre todo el arte quintaesencialmente español de la rejería, por el que sentía un entusiasmo rayano en la reverencia. 
En cambio el arte austero de la Contrarreforma le parecía antipático, y la arquitectura manierista francamente desagradable. Así pues, pese a sus esfuerzos por ser tolerante e imparcial, nunca pudo expresar otra cosa que respeto, sin el menor calor, por El Escorial.

Bernard Bevan será recordado por sus numerosos amigos y colegas con admiración por su entusiasmo y su originalidad, y con afecto por su solicitud, amabilidad y buen carácter. Su Historia de la arquitectura española, tal como fue escrita originalmente hace setenta años y publicada en versión española en 1950 y luego en 1970, se seguirá leyendo sin duda como un clásico de su época, y seguramente mantendrá largo tiempo su importancia para la historia del gusto y de la crítica.

JOHN BURY

\section{APROXIMACIÓN A LA ICONOGRAFÍA DE LAS ÓRDENES RELIGIOSAS EN LA AZULEJERÍA VALENCIANA DEL SIGLO XVIII}

El esplendor que caracteriza la azulejería valenciana del siglo xviII es notorio en la representación de santos y programas hagiográficos, rodeados de motivos y formas decorativas de singular belleza. Los pintores de azulejos, dibujan en estarcido sobre el esmalte estannífero, con perfiles en cobalto o manganeso de trazo fino (paños de azulejos de la Iglesia de Nuestra Señora de los Angeles en Chelva) (Fot. 12) o trazo grueso, para conseguir volúmenes y sombras como en el cuadro de azulejos de Santa Teresa en la fachada del antiguo convento del Carmen en Valencia. Los colores amarillos, ocres, naranjas, azules, violetas y verdes, iluminan un esmalte muy lechoso, característico de los talleres valencianos en azulejos que cubren suelos, o revisten muros en iglesias, ermitas, conventos o palacios. Estas obras fueron ponderadas por investigadores como Tormo Monzó, pionero en el estudio monográfico de la azulejería valenciana del setecientos en la arquitectura religiosa ${ }^{1}$.

En las escenas e imágenes que se representan, reconocemos un sentimiento piadoso que sigue apegado a la tradición, desapareciendo casi por completo complejas representaciones, para pasar a una reflexión más directa entre el artista que realiza la obra y las propias fuentes de inspiración.

Las imágenes dibujadas tienen los elementos iconográficos que les caracterizan y cuando la representación conlleva cierta complejidad, una filacteria o rótulo con el nombre del santo facilita la lectura iconográfica. El repertorio de los atributos de los santos, se reconocen como los símbolos que hacen referencia a su actividad (los útiles de trabajo de San José en la iglesia de los Santos Juanes de Meliana), los instrumentos del martirio (la rueda de molino de San Vicente en la iglesia de San Vicente mártir de Guadasuar) o las virtudes por las que tradicionalmente son reconocidos en la iconografía cristiana.

La devoción local favorece la representación de imágenes cuyos hechos y milagros se han destacado en Levante (San Vicente Ferrer, Santo Tomás de Villanueva, San Luis Beltrán). Estas advocaciones se popularizan en los retablos callejeros como expresión devocional colectiva. La obra de este género, llevó a crear conjuntos como el de la fachada de la iglesia del convento de

1 Tormo Monzó, E., «El arte barroco valenciano». Arte español. 1920-21. Tormo Monzó, E., Guías de Levante. Provincia valenciana y murcia. Madrid, 1926. Véase: Pérez Guillén, I., La pintura cerámica valenciana del siglo XVIII. I.A.M. Valencia, 1991. 